\title{
Kegunaan Crowdfunding
}

Oleh: Arella Kartikaputri

Email: arellaptr@gmail.com

Crowdfunding adalah sejenis crowdsourcing dengan memungkinkan pendukung online untuk terlibat dalam proyek sosial untuk berkontribusi pada sumber daya dalam mengatasi masalah sosial (Terras, 2015). Crowdfunding, sebagai jenis crowdorganising mencakup "transaksi spot, hubungan jangka pendek, harga berbasis permintaan, permintaan heterogen, dan reputasi yang dibangun melalui mekanisme umpan balik" (Powell, 2017). Digital Humanities adalah area di mana ilmu komputer dan humaniora bersinggungan (Terras, 2015).

Platform crowdfunding adalah contoh terbaik tentang bagaimana digital humanities memasukkan proyek-proyek spesifik yang menggunakan pendekatan humaniora untuk membangun sumber daya digital, yang meningkatkan minat luas pada humaniora itu sendiri (Rockwell, 2013). Ide menggunakan crowdfunding untuk membiayai digital humanity telah menjadi populer, tetapi beberapa pustakawan mempertanyakan apakah orientasi shifting fund dapat bertahan untuk jangka panjang (Reinsfelder dan Pike, 2018). Bukti menunjukkan bahwa wirausaha sosial mengadopsi crowdfunding dalam berbagai cara mulai dari donasi hingga crowdfunding ekuitas. Donasi crowdfunding memungkinkan wirausaha sosial untuk meningkatkan akses ke pendukung dengan mengadopsi praktik crowdfunding, yang ditandai dengan tidak adanya kedekatan fisik antara kelompok sasaran dan donatur.

Strategi yang dilakukan dalam mengadopsi crowdfunding adalah wirausaha sosial mengadopsi praktik crowdfunding berbasis amal, mengubah usaha sosial dari pasar terpusat untuk penggalangan dana menjadi lebih banyak partisipasi dengan dukungan dari pemangku kepentingan utama (Hergenrader, 2017). Crowdfunding juga menawarkan fenomena open source di mana para full-timer akan mengelola/ membantu platform yang kewalahan maupun kesulitan. Crowdfunding dapat membantu wirausaha sosial menghasilkan inovasi sosial sebagai produk yang dikembangkan untuk melayani masyarakat dengan lebih baik.

Beberapa artikel yang membahas crowdfunding dalam pemecahan masalah sosial:

Di Berlin, crowdfunding memang memungkinkan sosial entrepreneurship dengan cara-cara tertentu. Crowdfunding juga berkontribusi untuk memanfaatkan spekulasi dalam perkembangan real estate yang sedang berkembang pesat dan memfasilitasi ekonomi solidaritas kelompok komunitas dan badan amal. (Langley, Lewis, Farlane, Painter, Vradis 2020). Dengan menggunakan data yang dikumpulkan dari populasi kampanye crowdfunding AS(Amerika Serikat), mengeksplorasi interaksi antara gender dan target pendanaan kampanye, hasilnya menunjukkan bahwa kampanye mengumpulkan dana yang jauh lebih sedikit, karena jumlah target meningkat, ketika penandatangan utama adalah perempuan. Hasil ini adalah yang pertama menunjukkan hubungan antara gender dan pendanaan di antara populasi kampanye crowdfunding AS (Geiger, Oranburg 2018). Selanjutnya, crowdfunding dalam produksi susu di Cina. Dalam sampel survei dan wawancara, hasil menunjukkan bahwa kualitas susu, perbaikan gizi, pengurangan emisi, dan manfaat lingkungan yang dikaitkan dengan sistem PVWP terintegrasi merupakan faktor utama yang dipertimbangkan oleh narasumber yang menunjukkan niat untuk membeli susu. Hasil model regresi menunjukkan bahwa calon 
pelanggan dengan tingkat pendapatan yang lebih tinggi, dan mereka yang berada dalam usia parenting, dan mereka yang memiliki anak kecil atau berencana untuk memiliki anak, memiliki kemauan untuk membayar yang lebih tinggi daripada pelanggan lain untuk produk susu tersebut. Hasil ini dapat membantu produsen produk susu berkelanjutan untuk mengidentifikasi kelompok sasaran potensial di China dan memperkirakan permintaan pasar. Studi eksplorasi ini dapat memberikan kerangka kerja dengan penilaian kuantitatif dan kualitatif crowdfunding untuk sistem energi terbarukan dalam konteks nasional atau internasional. (Zhang, Campana, Liu, Wang, Yan, 2019). 


\section{REFERENCES}

Geiger, Mark., Oranburg, S.C. (2018) Female entrepreneurs and equity crowdfunding in the US: Receiving less when asking for more. Journal of Business Venturing Insights, 10, e00099.

Langley, Paul., Lewis, S., Farlane, C.M., Painter, J., Vradis, A. (2020) Crowdfunding cities: Social entrepreneurship, speculation and solidarity in Berlin. Geoforum, 115, 11-20.

Pratono, A.H. et al (2020) Crowdfunding in digital humanities: some evidence from Indonesian social enterprises, Aslib Journal of Information Management 72(2), 287-303.

Zhang, Chi., Campana, E.C., Liu, C., Wang, K., Yan, J. (2019) Crowdfunding preferences for a sustainable milk product with integrated photovoltaic water pumping system in China. Applied Energi, 255, 113649. 